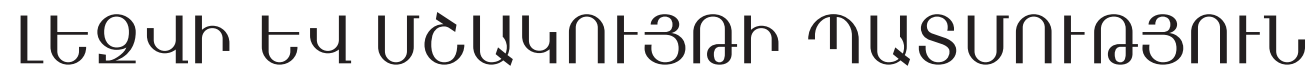 tu stunta3ntl
}

LALIK KHACHATRYAN

Doctor of Philology, Professor

\section{THE “NEW DICTIONARY OF THE HAYKAZIAN LANGUAGE” WITHIN THE CONTEXT OF FORMATION OF ARMENIAN LEXICOGRAPHY}

Key words:-metalanguage, polysemy, etymology, translating dictionary, explanatory dictionary, vocabulary structuring, structure of the word entries, semantic explanation, idiomatic version, grammatical description.

The Armenian printed lexicography originated in the beginning of the $17^{\text {th }}$ century, and also, in the mid of the $18^{\text {th }}$ century the work of three Mkhitaryan priests G. Avetiqyan, Kh. Syurmelyan and M. Avgeryan named the "New Dictionary of the Haykazian Language" was published in Venice (v.v. 1-2, 1836-37). The dictionaries of the Old Armenian language that were printed throughout the Armenian history certainly originated from the well-known NHD, such as the dictionaries formed by St. Malkhasyants, N. Buzandatsi, L. Khachatryan, R. Ghazaryan, L. Hovhannisyan.

In the field of the Armenian Studies NHD is certainly considered as the source of lexicography.

The first phase of The Armenian printed Lexicography begins early in the $17^{\text {th }}$ century and lasts until the late $18^{\text {th }}$ century. The first printed dictionary was a translation compiled by the Armenologist Francisco Rivola of St. Ambrose Parish, Milan
(DictionariumArmeno - Latinum, Milan, 1621), later by the Polish-Armenian Bishop AstvatsadurNersesowicz (Dictionarium Latino-Armenium, Rome, 1695).

The first translated dictionaries are succeeded by Classical Armenian Explanatory Dictionaries. The author of the first explanatory dictionary "BargirkHayots" is the medieval writer Jeremiah of Meghri (Alicorn, 1698). This was followed by the two-volume book "The dictionary of Armenian Language" (BargirkHaykaianlezvi) composed by the abbot of the Mkhitarist Order MkhitarSebastatsi (Venice, 1749-1769).

At the beginning of the $18^{\text {th }}$ century the Mkhitarist Order became an Armenological cradle where various monumental works of different characters sprang up, such as lexicographical, grammatical, bibliographical, religious, historical and philological.

But the masterpiece of the dictionaries is considered to be the work of three MkhitaristVardapets "New Dictionary of the Haykazian Language", published in two large volumes at St. Lazar printing house, Venice in 1836-37. This dictionary is otherwise named "New Haykazian Dictionary" (NHD). It was compiled thanks to the efforts of three outstanding Vardapets Frs. 
Gabriel Avedikian (1750-1827), KhachaturSurmelian (1751-1827) and MkrtichAvgerian (1762-1854).

Unfortunately, G. Avedikian and Kh. Surmelian did not live to see the publication of their work which took half a century to complete. M. Avgerian did his best to get the dictionary published ten years after their death. The latter outlived his friends by 27 years and died at the age of 92 . He succeeded in completing the dictionary alone by writing the main part and the foreword of the work and prepare it for publication. He even had to cut the manuscript down by publishing only two large volumes out of the 12 handwritten ones. Later on the material of this dictionary he wrote a concise "Handbook Dictionary" (1846). In 1865 this dictionary was revised and edited by a member of the Mkhitarist Order G. Tchelalyan and published in Venice as "Handbook of the Haykazian language".

The merits of the work of these Vardapets are as follows: the material of the dictionary consists of the original and translated manuscripts of the $5-17^{\text {th }}$ centuries and the authors used around 1000 manuscripts of the Mkhitarist Order library.

As a perfect explanatory dictionary, NHD presents the word stock of Classical Armenian in its real state, together with grammatical descriptions, semantic explanations, set expressions (idioms), specifying examples taken from various sources, parallel translations from classical languages, mentions of the source of borrowing, etc.

The authors of NHD came up with excellent solutions to the main problems of the dictionary which were the principles of the presentation of the word entries and the metalanguage.

Headword is a composite part of the word entry. In NHD headwords are given in alphabetical order and each headword gives some information on classical spelling, pronunciation and the position of the stress. Headwords are followed by word derivatives section, as in uuăumhu6nıphı or miăuhu6nıphiu, wuăumuntp or uluăuunhn, Łplhın//tipliın//tuplin// tulhn: Sometimes the synonyms of headwords are also provided, as qkpkquumuminn $\mathrm{h} / / \mathrm{q} \mathrm{k}-$ phquuulumunnilu, qkinuzluuph // qtipuzjuuphuqnju //, etc.

One of the composite parts of metalanguage is the explanation of the word meaning. Word meaning is aimed at bringing out the meanings of monosemic and polysemic words and interpreting them separately which presupposes the structure of an entry.

Various means of word meaning explanation are used in Lexicography, such as semantic or descriptive definition or the definition with synonyms or references, etc. All these means have been thoroughly used by the authors of NHD around 200 years ago.

Cf.

a) Semantic definition of a word (description): quuugnứu - qtinopbuqumgnnnıphiqnnju:Uhoquuluuu - np-

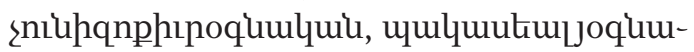
quinıptius, etc.

b) Definition with synonyms: Unkinu - unurwup, uminuunuup, umnpuip,

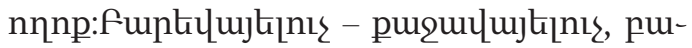

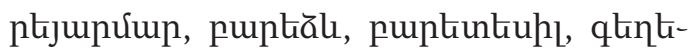
ghl, uquhı, ưuinnımumu:

c) Descriptive and synonymic definition:

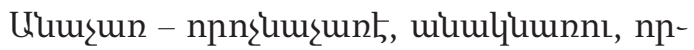

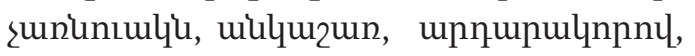
wujuunhn, uiluuuw], huunns.

d) Definition with references: a reference is a mention of a synonymic version which is written as See in English and unt'u S. in Armenian, cf. q56. S. q5e, q5p. S. qup, qpumbu. S. qpupup, etc. 
Each headword is described in terms of Grammar and Stylistics. The forms of declension and conjugation are mentioned. The headword is followed by its grammatical categories: in case of a noun: morphological value, the character of the declension, the flexion, the variants of declension, collocations and the number, and in case of a verb its voice and the formation of the second form.

For example, as a headword for a noun singular nominative case is provided, and for those nouns which do not have a singular form, plural nominative case is given, cf, Ulü - uluuu, uluurp, also'ulhiu, ulniup:Rnıuinp - quuntp.tupp, thuug or ting. q.: fuzun - h, hg or ug, q.: २upn - nı.nıg, nıp or quipn.pıq., etc.

In case of plural nouns: पuuरp - uug,

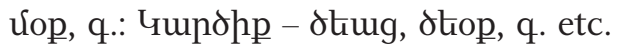

The following points are taken into consideration as to the verb: the past form (first person), the singular of the Imperative mood and the Voice: Unqupuluuv - uguj, ghín, 々:: Ftpku - płph, ptín, u.: quuu - quugh, quú, quughul, 乞. (The Past Participle is also given).

As seen from above, the explanation of headwords are presented by various means among which the semantic description prevails, followed by the enumeration of synonyms.

The authors of NHD have chosen a certain principle for the explanation of word meaning, that is to present the meanings of words chronologically. This principle consists in the fact that for each meaning of a word examples are brought from original texts in chronological order in the way these meanings occur in Literature. In terms of this principle NHD stops being merely an explanatory dictionary and acquires historical value. With the help of this dictionary one can learn the exact periodization of the semantic changes of Classical Armenian word stock as well as follow the chronology of original texts.

As Classical Armenian illustrations for word meanings, examples from the Bible are brought first, after which text illustrations from subsequent centuries are presented according to meaning.

Therefore, by following the semantic illustrations of words, we can state whether this or that word belongs to the $5^{\text {th }}$ century or not, which author it was first used by, since which century that word has developed new meanings and which writer used these particular meanings in his works, or whether this word is a borrowing or not.

As we have already mentioned above, NHD uses various means for the explanation of word meaning which ascribe an encyclopedic character to the dictionary. Thus, through mastering a number of foreign languages, the authors of the dictionary illustrated the equivalents of headwords with numerous languages, such as Greek, Latin, Arabic, Persian, Turkish, Assyrian, Hebrew, etc. This fact gives the value of translation to the dictionary.

The authors of NHD very often gave the etymology of headwords, thus ascribing an etymological value to the dictionary. Thousands of loanwords from Greek, Latin, Persian, Hebrew, etc, are provided with their exact etymologies in NHD.

The authors of NHD made typological comparisons of numerous words with Armenian and other languages, thus the word Uujn is compared to Sanskrit matar, Latin mater, Persian madar, the word Pnınu is compared with Greek phnu, Persian unpn, Sanskrit unlunu, Latin Porta, janua, vestibulum, the word Fuhp is compared with

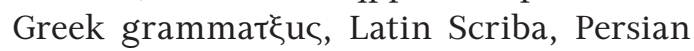
unhulyn, unıuphn, etc. Thanks to this fact the dictionary acquires a typological value.

The loanwords are specified with a special mark in the dictionary, and the lan- 
guage the word was borrowed from is also mentioned, as in Gupnnhlikuj - punju. qupolhqóu: Gupnnhll5 - pun.ju. qupolhqh', juun.qupólhqu: Ll hupkinp - ju.u[-

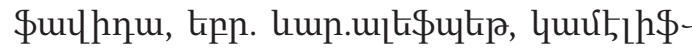
uls. Owing to this fact the present work has a value of a dictionary of borrowings.

Obviously, it is practically impossible to touch upon all the lexicographical values of NHD within the framework of one article. However, the superficial analysis presented here is enough to give an overall idea about the linguistic structure of the dictionary. The latter conditioned the huge progress which Armenian Lexicography made outside the limits of theMkhitarist Order.

After its publication NHD became the only authentic literary monument which all the specialists without exception dealing with problems of Classical Armenian relied on. NHD had such a high scientific value and strong magic power that no one even dared to make a lexicographical attempt.

Armenian Lexicography entered a new phase of development in the $20^{\text {th }}$ century: new dictionaries of various character sprang up, such as etymological and root, explanatory, for translation, specializedterminological, idiomatic, etc. There was even an attempt to make additions to the renowned NHD: we mean NorayrBysantine's lexicographical additions. The author gave descriptions of new word entries based on the recently-emerged literary texts. In 1990 M. Minasyan got this dictionary published in Geneva (New Dictionary of the Haykazian Language, edited and enriched by NorayrBysantine).

All sorts of dictionaries published in the Armenian reality can be unconditionally considered to have descended from the renowned NHD: first of all this refers to the choice of the word stock of the language, the structure of the word entries, semantic explanations, manifestations of polysemy, idi- omatic versions, translations from foreign languages, etymologies of root morphemes, manifestations in dialects, the metalanguage of the dictionary, etc.

Thus, in the1926-35sHrachiaAdjarian's "Armenian Etymological Dictionary" was published in Yerevan (in seven volumes). All the Armenian roots are included in this dictionary: each word is discussed through five separate sections. 1. Lexicology, 2. Etymology, 3.History of Etymology, 4. Dialectal words, 5. Loanwords from Armenian.

Two out of the five sections of the dictionary are based on the data from NHD: Lexicology for the most part and Etymology partially.

The lexicological section provides the root of a word, the declensional and conjugational forms of that root, the meanings and its definition, examples of usages of that word, other words derived from it and finally, its spelling. Etymology and etymological history sections touch upon the origin of roots, and various observations on that issue. The favourable impact of NHD is considerable in this part of the dictionary: in many cases the author confirms NHD's etymologies and continuously illustrates the Mkhitarists' ideas about roots in his section of History of Etymology.

In the1944-45s StepanosMalkhasiants' four-volume "Armenian Explanatory Dictionary" was published in Yerevan. This work presents the Armenian vocabulary beginning from the $5^{\text {th }}$ century Literature up to the literary language and dialects of modern times, borrowings made at different periods, the origin of the roots, appropriate examples of meanings, grammatical indices, etc.

We can undoubtedly mention that a voluminous work like this could not have been written but for the famous NHD's guiding data: firstly, this refers to the choice of the vocabulary of Classical Armenian, the in- 
terpretation of their meanings and, most importantly, the discovery of the original or old meanings of words. S. Malkhasiants, assuming NHD's reliable evidence as a basis, presents the old meanings of Classical Armenian with an asterisk.

The 1969-80s saw the publication of the four-volume "Explanatory Dictionary of Modern Armenian” in Yerevan, which was a result of a whole consortium of authors. It was during this period in 1976 that E. Aghayan published his detailed "Modern Armenian Explanatory Dictionary" in two volumes.

Albeit being a bit old-fashioned, these works are perfect explanatory dictionaries of the Armenian language which give a clear picture of the Armenian vocabulary, its sense, direct and figurative meanings, word-formation, spelling, idioms and setexpressions.

Although these kinds of dictionaries include the vocabulary of the Armenian language and its meanings, their lexicographical approaches are based on certain set and accepted principles which have come down to us thanks to the abbot MkhitarSebastatsi and his venerable students.

The influence that the lexicographical heritage of the Mkhitarists had in subsequent years, especially in the field of compiling Classical Armenian dictionaries, is overwhelming.

Around 160 years after the well-known NHD, in 1998 the first modest dictionary of Classical Armenian was published in Armenia which was written by the author of the present speech.

The dictionary is devoted to the layer of Classical Armenian vocabulary that had morphological polysemy in the period of Old Armenian. Certain lexical units of the language display more than one morphological value on the synchronic level.
Though we had the published concordance of Classical Armenian authors at hand while compiling the dictionary, the linguistic propositions, lexicographical principles and the semantic descriptions of Classical Armenian words proposed by NHD's authors served as guidelines for us throughout our work. We have devoted the dictionary to the bright memory of our outstanding lexicographers G. Avedikian, Kh. Surmelian and M. Avgerian and to their richly-endowed merit, that is, the $160^{\text {th }}$ anniversary of the publication of their lexicographical monument "New Dictionary of the Haykazian Language".

Continuing our studies in this field we published the revised variant of this dictionary in 2003, namely, "Explanatory Dictionary of Classical Armenian: morphologically polysemantic words". Using the literary monuments of Classical Armenian we bring examples for each of the dichotomic value of morphologically polysemantic words from original texts. We undoubtedly had NHD's guiding data as a basis for our research.

R. Ghazaryan's two-volume "Dictionary of Classical Armenian” was published in Yerevan in the year 2000. This is a complete dictionary based on the principles of not only NHD, but also "Handbook Dictionary": it has enriched Classical Armenian vocabulary to a certain extent due to the data from new sources of Literature. We can directly state that this dictionary is a transformation of "Handbook Dictionary" into New Armenian or Ashkharhabar. This is a unique dictionary in its kind and thanks to it specialists will not find the tedious work of translating Classical Armenian original texts difficult any more. In view of the Mkhitarists well-known dictionaries, R. Ghazaryan also compiled "Classical Armenian Dictionary of Synonyms” (Yerevan, 2008) and "Classical Armenian Dictionary 
of Idioms" (Yerevan, 2012). Unfortunately, the latter was published posthumously. In 1987-92 he published the two-volume "Middle Armenian Dictionary" together with $\mathrm{H}$. Avetisyan. The Classical Armenian words and their meanings used in Middle Armenian were interpreted via NHD's trusted data in this dictionary.

2010 saw the publication of L. Hovhannisyan's "Dictionary of Classical Armenian: words not mentioned in "NewHaykazian Dictionary". It included words, styles and idioms the author had taken from old Armenian Literature. After the publication of Haykazian Dictionary a lot of researchers (N.Byuzandatsi, H. Acharyan, Aris,Vardanyan and others) on various occasions reverberated these "newly-found" and "novel" words not touched upon in the dictionary. And L. Hovhannisyan, having Mkhitarist Vardapets' masterpiece at his disposal, compiled and explained numerous new words in accordance with textual evidence. The authors of NHD were most probably not acquainted with these original texts. The present dictionary is a unique completion of the renowned NHD's wordlist and explanations of word entries.

As we have noticed, nowadays Classical Armenian Lexicography has seen an explosion of interest: we want to emphasize once again that the fundamental works created by the Mkhitarists have greatly contributed to this.

In 2013 we authored and published "Classical Armenian Educational Dictionary”, which presented Old Armenian vocabulary from Armenian Literature of the 5-12 centuries, selected by certain principles. We included the material of those literary monuments which have to do with the problem of translatability of Classical Armenian original texts and are in the curriculum of universities intended for students studying Classical Armenian.
We want to round up our speech with a quotation from the foreword of our own dictionary, "It is impossible to undertake a Classical Dictionary of any kind and not to draw parallels with the fundamental and ground-breaking "New Dictionary of the Haykazian Language". The lexicographical monument compiled by the venerable Mkhitarists is a wealth of a word stock of Classical Armenian together with the explanations of word-meanings and their nuances, examples from original texts, grammatical descriptions, phraseological units, sources of borrowings and comparative translations from a number of languages. "Handbook Dictionary", which is not less well-known, has also served as an essential source of the precision of Classical Armenian vocabulary and word-meanings for us. The latter has been enriched by around five thousand words and word combinations in comparison with NHD" (pages 3-4).

It is certainly undeniable that the MkhitaristVardapets' lexicographical heritage played a great role in other spheres of Armenological developments as well: what we mean here are the Classical Armenian textbooks, the research papers devoted to the Armenian language, the synchronous studies on the various existential conditions of the language, thesis papers of various types, etc.

As specialists of Classical Armenian and authors of textbooks and dictionaries, we fully confirm that G. Avedikian's, Kh. Surmelian's and M. Avgerian's richly-endowed merit is a literary monument of not only Armenian Lexicography, but also Armenian book printing in general. Finally, the following description suitable for Homer's work, can also be extended to it: it is a literary monument which has the definition of both being unreachable and unexcelled. 


\section{REFERENCES}

1. E. Aghayan, Modern Armenian Explanatory Dictionary, Yerevan, 1976.

2. H. Adjarian, Armenian Etymological Dictionary, v.v. A-D, Yerevan, 1971-79.

3. Handbook Dictionary, Venice, 1865.

4. Explanatory Dictionary of Modern Armenian, v.v. A-D, Yerevan, 1969-80.

5. L. Hovhannisyan, Dictionary of Classical Armenian: words not mentioned in New Haykazian Dictionary, Yerevan, 2010.

6. L. Khachatryan, Explanatory Dictionary of Classical Armenian Polysemantic words, Yerevan, 1998, Explanatory Dictionary of Classical Armenian: morphologically polysemantic words, Yerevan, 2003, Classical Armenian Educational Dictionary, Yerevan, 2013.

7. R. Ghazaryan, Dictionary of Classical Armenian, v.v. A-B, Yerevan, 2000. Classical Armenian Dictionary of Synonyms, Yerevan, 2006. Classical Armenian Dictionary of Idioms, Yerevan, 2012.

8. S. Malkhasiants, Armenian Explanatory Dictionary, v.v. A-D, Yerevan, 1944-45.

9. New Dictionary of the Haykazian Language, v.v. A-B, Venice, 1836-37.

10. New Dictionary of the Haykazian Language, edited and enriched by NorayrByuzandatsi, published by M. Minasyan, Geneva, 1990.

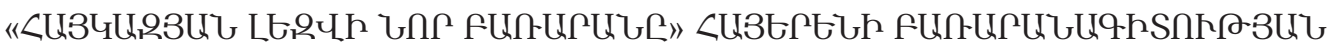

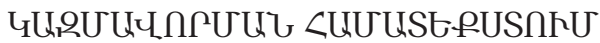

\section{LULFY FUUQSP3U乙}

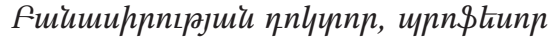

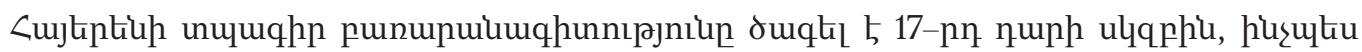

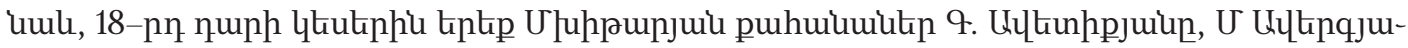

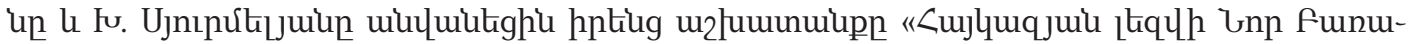

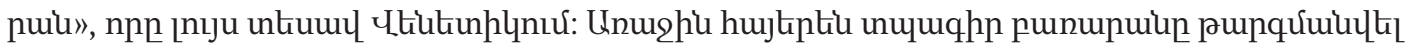

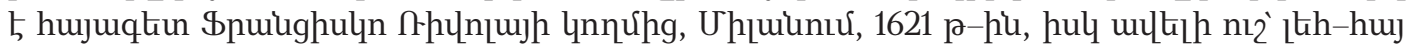

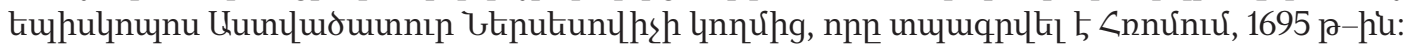

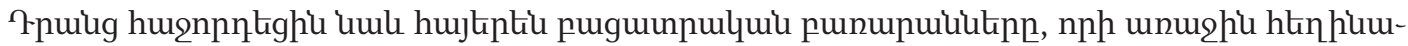

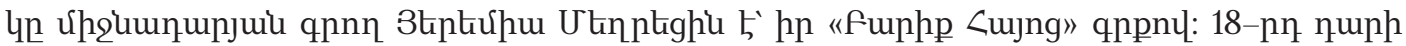

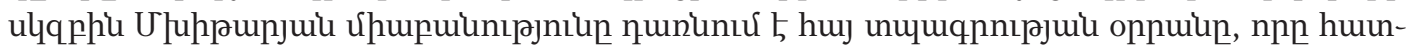

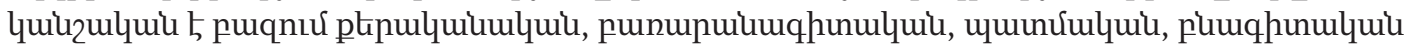

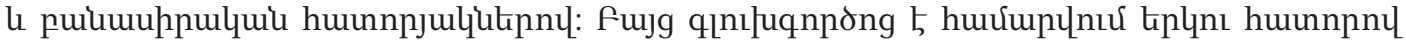

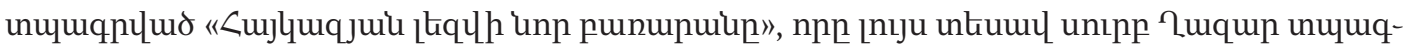
puinuin, thithunhlynuर, 1836-37рр.:

\section{„НОВЫЙ СЛОВАРЬ ГАЙКАНСКОГО ЯЗЫКА” В КОНТЕКСТЕ ФОРМИРОВАНИЯ АРМЯНСКОЙ ЛЕКСИКОГРАФИИ}

\section{ЛАЛИК ХАЧАТРЯН}

Армянская печатная лексикография сформировалась в начале XVII века, а в середине XVIII века в Венеции был издан труд трех духовных отцов - Г.Аветикяна, Х.Сюрмеляна и 
М.Авгеряна - “Новый словарь гайканского языка” (тт. 1-2, 1836-1837).

Все словари древнеармянского языка, изданные в армянской действительности, безусловно, исходят из общеизвестного НСГ. Таковыми являются словари, составленные Ст.Малхасянцем, Н.Бузандийским, Л.Хачатряном, Р.Казаряном, Л.Оганесяном.

Принципы, разработанные в НСГ, относятся к выбору словарного состава языка, структуре словарных статей, смысловым объяснениям, проявлениям полисемии, фразеологическим единицам, переводу на другие языки, этимологии, диалектным вариантам, метаязыку и т.д.

В области арменистики НСГ безусловно считается непревзойденным памятником лексикографии.

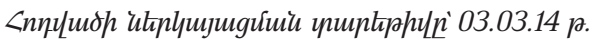

